\title{
Community Multicultural Integration Pattern in Environment-Based Learning
}

\author{
Munardji \\ Assoc. Prof., Education Departement, Institut Agama Islam Negeri Tulungagung \\ (IAIN), East Java, Indonesia, munardji@iain-tulungagung.ac.id
}

\section{Nur Kholis}

Assoc. Prof., Education Departement, Institut Agama Islam Negeri Tulungagung, East Java, Indonesia, nurkholisblt@iain-tulungagung.ac.id

\section{Nuril Mufidah}

Universitas Islam Negeri (UIN) Maulana Malik Ibrahim Malang, East Java, Indonesia. nurilmufidah86@uin-malang.ac.id

This study was aimed to analyze the cultural diversity of Madrasah Ibtidaiyah Negeri (MIN) of Tegalasri, a multicultural school community in Indonesia and synthesize patterns of multicultural integration of the Tegalasri community in environmental education. Two research questions were dealt in this study; they were (1) What forms of cultural diversity exist in the community in MIN? and (2) How is the pattern of environment-based school development in MIN? This research was qualitative in nature with a case study approach. 13 subjects were involved in the study consisting of the school principals, teachers, students, parents/guardians, and school committees. Data were collected through tin-depth interviews, documentation, and observation techniques. Data analysis was carried out in interrelated stages of data presentation, data reduction, conclusion drawing, and verification. The results showed that the Tegalasri community possessed a diversity of cultures that could be seen from religion, socio-economic, relationships between individuals and groups in society, and religion-based arts and culture. The patterns of multicultural integration of the community in the development of environment-based schools in MIN were in the form of forming a core team, formulating the school roadmap, establishing internal and external cooperation, conducting joint activities with the community, and integrating with the school curriculum. The theoretical findings of this study are an example of the development of environment-based schools.

Keywords: multicultural integration of society, environmental education, learning, community

Citation: Munardji, Kholis, N., \& Mufidah, N. (2020). Community Multicultural Integration Pattern in Environment-Based Learning. International Journal of Instruction, 13(1), 101-124. https://doi.org/10.29333/iji.2020.1317a 


\section{INTRODUCTION}

Education has a close relationship with the surrounding social environment (Lieberman \& Hoody, 1998). Using the environment as a context for learning certainly brings great impacts on student achievement. It also develops student abilities to transfer knowledge to new contexts (Glenn, 2000). Keil, Haney, and Zoffel (2009) emphasize performance scores for both measures and support for further use of the integrative problem-based environmental health science curricula. The dynamics of school management, learning, school financial management, and school evaluation cannot be separated from the dynamics of the surrounding community. Proper school management requires collaboration among various parties around the school, both individually and institutionally. Learning developed by teachers should have secure connectivity with the socio-cultural aspects of the surrounding community so that learning outcomes can be implemented and have good quality output and outcome. Thus, school principals and teachers must be sensitive and always update policies, school managerial patterns, and their leadership with the dynamics of the surrounding community, both on an international, national, regional and district/city scale.

A school is a place for seeding values, norms, and culture to develop the character of students so that they can contribute to developing a good culture of society. Every school always has a distinctiveness that is imaged through a long process in developing the resilience of schools. School resilience is a way of thinking that schools are the environment or the area where the learning process is held, where the values of life and personality, religion, and various kinds of technological knowledge and skills are embedded (Wangid, 2009). Schools should also be seen as a system that has a relationship with sub-subsystems in society and other systems, and thus the relationship between cross-institutions is a necessity. School development is to be inspired from Pancasila and the 1945 UUD which always moves and develops with time and always comes from religious, cultural values (Sisdiknas, 2003). Among the social subsystems that have a close relationship with the school are social systems which include religious, cultural, political, economic, and social norms.

The relationship between schools and other sub-systems in society is reciprocal. Schools function to instill religious social values and norms with their students, while the community functions to develop behavioral changes. The ability of the school to synergize with the existing sub-systems in the community can improve the quality of learning and have an impact on improving the community system in the future, this is the function of the school for the community. Research conducted by Kholis, Zamroni, \& Sumarno (2014) shows that community participation (parents/guardians of students, institutions in the village, business institution) can enhance and stimulate learning, both in the classroom and outside the classroom. In addition, schools contribute to changing people's behavior for the better one. The school management model that involves the whole community can increase community responsibility for the school because they feel they have an obligation to the school they have built and they also have a sense of being involved in developing the school. 
Most previous studies such as those conducted by Akkoyunlu \& Yilmaz-Soylu (2008), Neo \& Neo (2001), Chou \& Liu (2005), Jong \& Chan (2018), Ernest \& Monroe (2004), and Ayala \& Yano (1998) were focused on environment-based learning. Some other researchers focused on schools as a system, as research conducted by Lavonen, Juuti \& Meisalo (2005). Only few who researched environmentally friendly schools or green school.. Gordon (2010) and Yeh (2018) were among those few. It is necessary, then, to deepen and enrich the study of how to synergize the potential of subsystems in the community with the potential of schools, so that schools and communities have a social function to develop values, norms, and

Based on the important role of good relationship between school and community, the importance of environmental education for the students, as well as the fact that only few studies have been conducted in that matter, this study is intended to fill such research gap by examining the culture of harmony in a multicultural society and revealing the pattern of integrating environmental education in schools with the potentials of the cultural diversity of the community. To be more explicit, two research questions were formulated for the present study as the followings:

(1) What forms of cultural diversity exist in the community in MIN Tegalasri?

(2) How is the pattern of environment-based school development in MIN Tegalasri?

The results of the study in the form of patterns of integration of multicultural community into environment-based education are considered very significant in providing models that can be understood and applied by other schools to develop an ideal environmentbased school through creative and innovative efforts by utilizing the internal potentials of the school and the external potential of the community. In the long run, having an ideal environment-based education, schools have an important role in producing students who have good understanding, loyalty, and skills to harmonize the environment so that it is beneficial for the sustainability of the ecosystem.

\section{LITERATURE REVIEW}

\section{Community Multicultural Integration Pattern in Environment-Based Learning}

Multicultural curriculum enactment (Epstein, 2010) may be suggested for educationbased community. Every student brings culture that must be communicated and transferred to other student. Curriculum as values and norms in the school should be considered by all elements of community in schools. Concord able religious education, this is because material is the content of education which includes knowledge, value planting and attitude formation (Nugroho \& Nikmah, 2018) with multicultural students in the class. Then, a teacher should teach by avoiding fanaticism in the class room. Not only in the class room, multicultural in university setting, has potential implication for sociocultural awareness (Ambele \& Boonsuk, 2018) and avoiding fanaticism and its need in the community of learning. The multicultural education movement in Freire's opinion, that the flow of education has begun to open to the principles of understanding and acceptance, not just tolerance but rather leads to a form of respect for diversity, based on the need for educators teaching approaches shows a description of the support 
of the features of race, class, and gender in learning settings. Multicultural education is a valid call for educators who are aware of cultural studies, so that it can be applied in the classroom because educators conceptualize multicultural education in theory and practice (Balaji \& Millstein, 2017). Multicultural is not local issue in MIN Tegalasri, but multicultural is issue in world. Table 1 can be the theoretical and inspiration for practical this research.

Table 1

Previous Multicultural Studies in the World

\begin{tabular}{|c|c|c|}
\hline No & Researcher & Views about multicultural education \\
\hline 1 & $\begin{array}{l}\text { Bal and } \\
\text { Bianco, } 2016\end{array}$ & $\begin{array}{l}\text { Multicultural education comes from the socio-political context of ethnic revitalization, decolonization, and } \\
\text { the civil rights movement, whose main purpose is to improve educational outcomes for minorities. The } \\
\text { multicultural paradigm of students who are trying to resolve inequality through changing anti- } \\
\text { discrimination policies. "Creating a School culture that provides comfort for personality development" } \\
\text { The multicultural education movement includes activities related to curriculum development, reducing } \\
\text { prejudice, innovation in teacher education and pedagogical practices. Multiculturalism is influenced by the } \\
\text { sustainability of global economic activities and routine national-scale activities that now exist everywhere } \\
\text { in population mobility, war, activism, and network and communication technology. }\end{array}$ \\
\hline 2 & Bianco, 2016 & $\begin{array}{l}\text { Multicultural of education in Australia related to an oppression of indigenous peoples and the politics of } \\
\text { reconciliation, geographical unrest, US immigration, the economy, crisis and rejuvenation, educational } \\
\text { experimentation and innovation. Broader demographic, geographical and economic themes, historical } \\
\text { studies, neoliberal-based education reforms, policies of prevailing political ideology. Multicultural } \\
\text { education programs in the form of English teaching programs as as an important communication tool for } \\
\text { immigrants of all ages, while still using it of the first language for immigrant and native children or as a } \\
\text { mother tongue mantra, teaching community / heritage languages, instilling diverse cultural perspectives in } \\
\text { all curriculum subject areas, such as history, geography, citizenship studies, parental participation, and } \\
\text { active combat of negative and / or racist depictions of minority populations. } \\
\text { There are big inspiration and implementation in Australia with multicultural education go beyond ideology } \\
\text { that influences the politic differences to be included in development and formulation of curriculum }\end{array}$ \\
\hline 3 & $\begin{array}{l}\text { Joshee et al, } \\
2016\end{array}$ & $\begin{array}{l}\text { Multiculturalism in Canada exclusively refers to a concern for cultural diversity, thereby overcoming the } \\
\text { problem of integration of immigrants, cultural identity, racism, religious diversity, and linguistic diversity. } \\
\text { Education is always seen as the key to ensuring that cultural diversity is well managed and provides } \\
\text { examples of multicultural education practices in teaching and leaning. Examination of curriculum and } \\
\text { standards in social studies education in Canada shows diversity, through acceptance and appreciation, to } \\
\text { justice. }\end{array}$ \\
\hline 4 & $\begin{array}{l}\text { Wang, et.al } \\
2016\end{array}$ & $\begin{array}{l}\text { The Study of Historic of Chinese in understanding linguistic education policies for multicultural education } \\
\text { groups in the setting of Chinese education policies assuming an important place in the Chinese education } \\
\text { system. During this period, multi-ethnic identity has been considered a broader and more inclusive } \\
\text { component of China's national identity. The country of China is a multicultural country where several } \\
\text { ethnic groups have lived for a long time. So they have become part of the country of China. China is also } \\
\text { known as a figure in the economic field as well as in political matters. even in the global contexts, China } \\
\text { is seen as a penetrating figure in cultural progress.. The growing interest in international dialogue on } \\
\text { multiculturalism and multicultural education can help to provide more counter discourses that might be } \\
\text { taken up in the Canadian context for talking of debate about religion. }\end{array}$ \\
\hline 5 & Horst, 2016 & $\begin{array}{l}\text { As for the diversity of tribes in Denmark context there is a group that is generally classified as marginal } \\
\text { group's e and low education among ethnic minority students. A brief theory of the relationship between } \\
\text { understanding multicultural societies and understanding multicultural and intercultural education so that } \\
\text { education is needed (school regulations, curriculum descriptions, and teacher education) and initiatives } \\
\text { between teachers and principals in various areas relating to the central aspects of multicultural and cross- } \\
\text { cultural education. } \\
\text { What can be used as an example of multiculturalism is a view of the concept of differences in 'culture' and } \\
\text { its development in the science of learning, including in the field of political philosophy, and the emergence } \\
\text { of public understanding. } \\
\text { In habituating learning at school between students also raised the principle of similarity. Equality in } \\
\text { understanding each other's ethnic, cultural and social differences. }\end{array}$ \\
\hline 6 & $\begin{array}{l}\text { Chamlian } \\
\& \\
\text { Kowalewski, } \\
2016\end{array}$ & $\begin{array}{l}\text { In the case of Brazil, It is well known that multiculturalism in the Barzil country has become one of the } \\
\text { subjects taught in schools at the same level as other subjects. Differences in political and social economic } \\
\text { conditions become critical studies in learning so that through this critical thinking students at school can } \\
\text { be pilots of understanding and implementing equality in various ways. even conversations about racial } \\
\text { tolerance, cultural differences and democracy became part of learning and becomes a problem in }\end{array}$ \\
\hline
\end{tabular}

International Journal of Instruction, January $2020 \bullet$ Vol.13, No.1 


\begin{tabular}{|c|c|c|}
\hline & & education. \\
\hline 7 & $\begin{array}{l}\text { Soudien } \\
\text { and } \\
\text { McKinney, } \\
2016\end{array}$ & $\begin{array}{l}\text { South Africa ss a country known for high diversity, as sight seems to be a clear as place political that } \\
\text { manage the development of multicultural. Its diversity, more than that, is significant impact on politics, } \\
\text { social and economic difficulties. Significantly, political laws and political protection have been created in } \\
\text { the framework of developing the multicultural model of schools and becoming part of the school system. } \\
\text { Steps in curriculum reform The main policy instrument is the Law School of South Africa (SASA). So that } \\
\text { multiculturalism in education is shaded by state laws. The case of South Africa emerging multicultural } \\
\text { policies are an important benchmark for education scientists. }\end{array}$ \\
\hline 9 & Bal, 2016 & $\begin{array}{l}\text { There are differences in construction in the United States it has been agreed that there are differences in } \\
\text { racial language classes and are part of multicultural education There are demographic changes that } \\
\text { underline the need for national policies to address diversity and new populations including policies that } \\
\text { take into account the increasing diversity of immigrants and skilled citizens. Educators must understand } \\
\text { the history and cultural context of student life to develop multicultural classes and curricula. Activities } \\
\text { related to cultural participation in accordance with the theory of social culture become learning for the } \\
\text { community to adapt to various cultural models. in line with social change, cultural development will } \\
\text { continue to run in the community lived by the community. Culture provides structured and structured tools } \\
\text { by learning people in certain there is a mixture of interests between the social aspects, power, goals, } \\
\text { practices and history of each individual and the exchange of civilizations. In the United States, an } \\
\text { understanding of multiculturalism leads to a celebration of diversity and individuality towards the creation } \\
\text { of a national curriculum that paradoxically is both pluralistic but united with culture. }\end{array}$ \\
\hline 10 & $\begin{array}{l}\text { Bianco } \\
\text { and } \\
\text { Slaughter, } \\
2016\end{array}$ & $\begin{array}{l}\text { Thailand multiculturalism emphasizes the importance of assimilation of minorities to established and } \\
\text { special norms at home and internationally, as a country that embraces ethnic homogeneity. } \\
\text { There are multicultural peculiarities in Thailand where in the Siamese kingdom demographically and } \\
\text { geographically the basis for multiculturalism. So the curriculum in the school reflects and reinforces } \\
\text { multicultural history in Thailand. Multicultural practices are student-cantered, have the opportunity to } \\
\text { transform all students' needs in culture and reflect on their ideals and self-identity. Multi-cultural cognitive } \\
\text { and affective influence on the development of their attitudes. Culture to understand themselves and others } \\
\text { leads students to be pioneers in social change and social culture including religion. }\end{array}$ \\
\hline 11 & Bianco, 2016 & $\begin{array}{l}\text { The concept of 'multicultural' as a discussion for shaping public education and education policy. Diversity } \\
\text { is very dependent on the historical perceptions about the relations of each country in the regulation of } \\
\text { differences and how the question of difference relates to the material and symbols of each. } \\
\text { Building conversations the comparison that needs to be voiced in learning is the discussion about } \\
\text { ethnicity, pluralism and language and will be a constant over time, opinions about to policies and practices } \\
\text { that are based on local experience of global development patterns stemming from economic and political } \\
\text { upheaval. } \\
\text { Multicultural education is very much influenced by globalization. Globalization has allowed an } \\
\text { international flow of knowledge, in culture there is a relationship between individual cultures with each } \\
\text { other. Because it cannot impose cultural homogeneity because cultural differences often occur. All } \\
\text { countries even cannot be separated from multicultural economic impact on the community. All work } \\
\text { together to provide support for different cultural content from one another. }\end{array}$ \\
\hline
\end{tabular}

Table 1 can be concluded that multiculturalism in education is a global issue and its main globalization is in Turkey, Canada, US, Thailand, China, North Africa, and Brazil. each country has its own way of how multiculturalism can be embedded in society in the world of education, whether through curriculum policy, political policy, government policy, or from the demands of minorities. This can be a theoretical basis and have implications for applying multiculturalism in education. Table 1 each country has its own way of including multiculturalism in education. The views on Table 1 can be a theoretical basis and have implications for applying multiculturalism in education. Table 1 each country has its own way of including multiculturalism in education.

To strengthen multiculturalism there is a Quran surah al Hujurat verse 13 which inspires that humans need multiculturalism from all ethnic groups and religions to gain benefits in cultural life, take advantage and knowledge from each other. As the following verse reads 


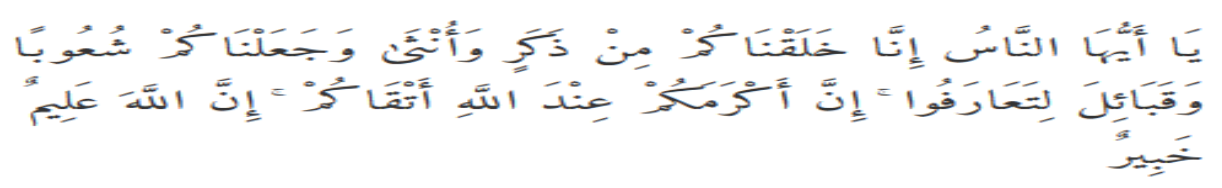

The current research is focused on the MIN Tegalasri school setting and seeks to provide equal treatment to all study participants who bring cultural, religious, racial economic differences. Multicultural is also closely related to the term immigrant, racial, economic, political, government policies in a country, history, demography, gender in each country. Then multicultural education is conceived so that all citizens get the same equality for call citizen to get education.

Schools and communities cannot be separated, both theoretically and practically. Building interfaith alliances in education also involves overcoming tensions that exist within the religious community (Balaji \& Millstein, 2017) if in education using a multicultural approach. Various studies show that society has an important role in developing quality schools (Budimansyah, 2008; Kholis, Zamroni, \& Sumarno, 2014)), in transforming community culture into school culture (Ruyadi, 2010), and in improving the quality of schools through community participation (Rahman, 2012). In addition, schools also give important contribution to the development of culture and human resources and preparing new generation in advancing society (Sudarsana, 2016; Roza, 2007). The relationship between the school and the community is thus historically in the dynamics of relevant community development to continue to be developed in various innovative forms according to the dynamics of the community so that the school becomes more efficient and effective. The community can establish schools to develop and institutionalize subcultural cultures, for example, religious educational institutions, besides being intended to instill social-national values as well as religious values so that religion still exists in the increasingly accelerating dynamics of society. It means that this is important because teachers as part of community may conceptualize the association of science with daily life as meaning that scientific knowledge should be transferred to everyday contexts instead of perceiving it as requiring the adoption of a daily life context-based learning approach (Leito et al., 2019) no exception in what kind of community would be formed by the teacher and the environment.

School is basically an institution for seeding values, knowledge, attitudes, and national and religious behavior so that students can play a role and have responsibility for the people and nation (Desfandi, 2015). The theories taught to students in schools should have a function in increasing their knowledge and skills in acting out their social functions. A right school is one that has the function of transmitting knowledge and skills, and optimizing the potential of students, and having good character. There is little doubt that different cultures utilize different characteristics of persons in determining social distance (Burns, 1984) when a school declares as multicultural school. The optimization of students' self-potential is expected to be used to explore and utilize their external potential so that their presence becomes more meaningful. Thus, the school has meaning for the community, and conversely, the community can contribute to the achievement of school goals effectively and efficiently. In radical social psychology, the 
values of commitment used are the values of pluralism, multiculturalism, and anti-racism invested in empirical studies and educational statistics in multiethnic settings (Verma \& Bagley, 1984). Multicultural education incorporates the idea that all students regardless of their gender, social class, and ethnic, racial, or cultural characteristics should have an equal opportunity to learn in school (Chouari, 2016), so when a school appropriate all of aspect multicultural, that school should become multicultural approach in teaching and learning.

Schools that can attract such students are schools that are able to transmit the culture of local people into organizational / school culture, as the results of research conducted succeeded in showing that the culture of the surrounding community can improve organizational performance, after cultural variables are derived from social norms, and each cultural dimension in question, namely; power distance, uncertainty avoidance, individualism / collectivism, and masculinity / femininity. Synchronizing the culture of the local community into the school culture is not only meaningful for the school concerned but also intended for the knowledge gained by students to be grounded. Education does not only provide knowledge and skills but more than that it is also intended so that students have a guideline of values and norms in the practice of their daily lives (Efianingrum, 2007), so the school must be grounded. Transforming the culture (Giorgetti, 2017) of the local community into school culture and vice versa is a necessity because the school produces outcome which later plays a role in society. Therefore, the collaboration between schools and religious leaders, community leaders, and other figures and institutions in the community becomes important.

Research conducted by Rahman (2014) shows that the participation of parents/guardians/ communities through school committees can influence students' competency knowledge, attitudes, and skills (Sarjono \& Mardapi, 2018). The involvement of parents in schools varies, for example being involved in the management of school committees, class associations, performing activities for students conducted at the end of the semester or at the end of the year, involved in the physical construction and school environment or the construction of public facilities in schools. Building good relations with parents/guardians of students can accelerate the achievement of school goals, both related to academic aspects and environmental aspects, and school culture. In many ways, the involvement of parents/guardians as the results of a study conducted by Kholis et al. (2014) shows that the involvement of parents/guardians can accelerate the achievement of school goals, interacting with all element of schools (Ambele \& Boonsuk, 2018). Schools have a variety of targets and objectives within a certain period of time. For example, the State Islamic Elementary School (MIN) Tegalasri aims to be a school that teaches students to have environmental awareness (adiwiyata school). It is necessary to involve parents/guardians in planning, implementing and evaluating environmentally friendly learning and development programs for school culture life. They can participate in developing a culture of love for the environment in the family environment, participating in the go green program at the school, supporting books related to the love of the environment, supporting activities at the end of the year and at the end of the semester about the performance of students. 


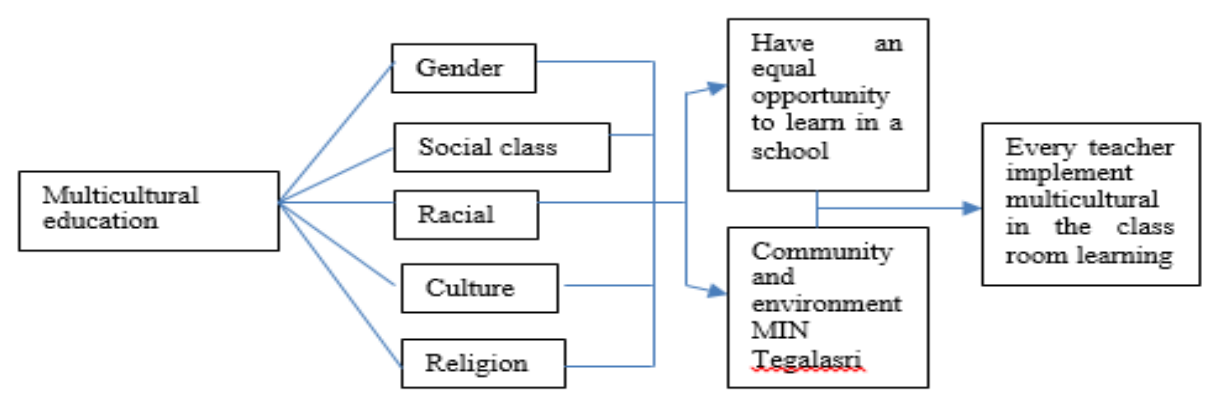

Figure 1

Research Paradigm

\section{METHOD}

\section{Type and Research Approach}

This research was qualitative using a case study approach. The study was conducted from August to October 2018. The timing of the study was adjusted to the active day of learning so that it was expected to obtain accurate data by integrating the techniques of in-depth interviews, observation, and documentation. The research was conducted at MIN Tegalasri, Wlingi, Blitar, East Java. Site selection was based on the considerations that the school is a pilot of the national level of adiwiyata school, the level of stakeholder participation is quite good, and environment-based learning is implemented at the school. The school itself is located in Tegalasri village in which its community embraces different religions, namely; Muslim, Christianity, Catholicism, Hinduism, and Buddhism. Since such religious diversity was certainly believed to have an impact on cultural diversity, and on how the people socialize with others and view education for their children, the ability of the school to integrate multicultural aspects of society in learning was considered exciting since mainly the school studied was located in Moslem society. Hence, MIN Tegalasri was considered appropriate as the site of the research based on the school's unique characteristics.

\section{Subject of Research}

The subjects of this study included one school principal (53 years old), 3 vice principals (60 years old, 45 years old, and 35 years old respectively), 5 teachers ( 25 years old, 29 years old, 31 years old, 43 years old, and 52 years old respectively), 2 school committees ( 35 years old and 53 years old), and 2 parents ( 35 years old and 45 years old). Thus, the total number of subjects of this study was 13 and they were selected based on the criteria of having good understanding of the learning process, being directly involved, and being active in the learning process which was integrated with local multicultural communities. Figure 2 shows the subject of the research. 


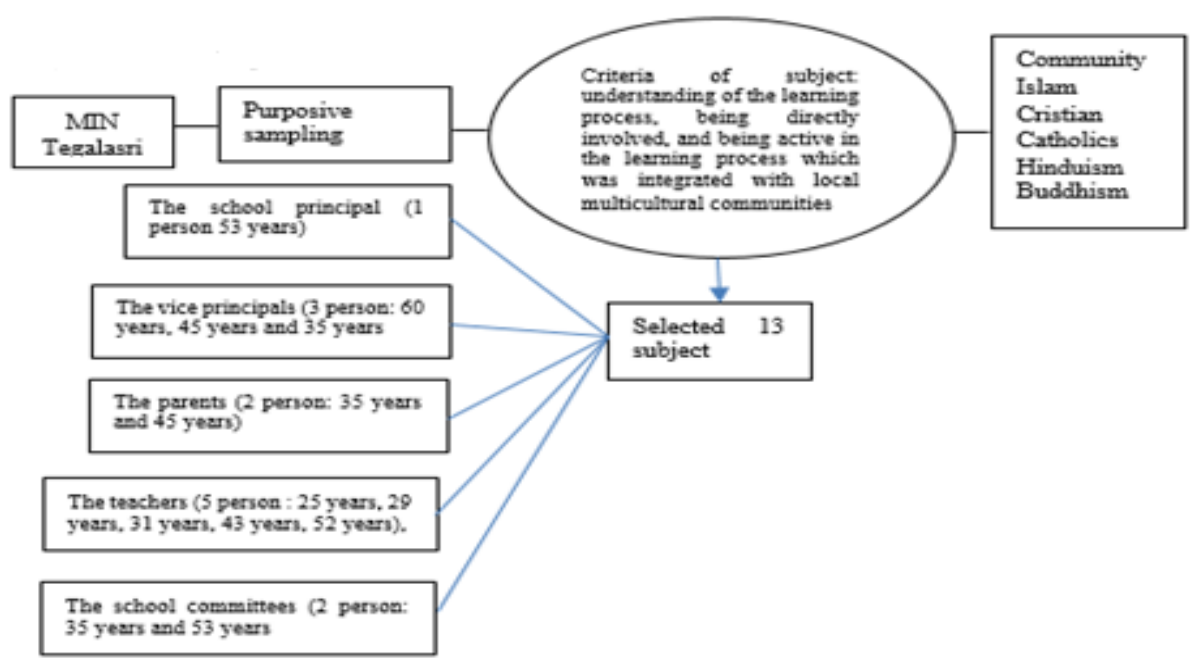

Figure 2

Subject of the Research

\section{Data Collection}

The data in this study were collected by in-depth interviewing, documentation and observation techniques. In-depth interviews with subjects were related to; 1) Types of multicultural society in Tegalasri, which include; religion, socialization between people of different religions, neighbor relations, mutual cooperation, the culture of educating children, and social capital; 2) patterns of integration, which include; collaboration between internal and external elements of the school, the formation of a core team, the creation of a school roadmaps, an increase in community participation, and a pattern of integration into learning.

\section{Data Validity}

The four main things were used as the basis for determining the validity of the data, namely; truth value, application, consistency, and neutrality. Determining credibility of data was carried out with several techniques including considering the adequacy of data collection time (initially planned for two months plus three months), always checking with various data collection techniques, and asking for peer reading. The application is intended to ensure that the method or procedure of the research carried out can be done elsewhere. Therefore, this method of trial research elsewhere has similar characters, namely in the Village of Maron, Srengat District, Blitar Regency. While to fulfill consistency (dependability) and neutrality (confirmability), besides asking for readings from peers, researchers also read and edited several times.

\section{Data Analysis}

Data analysis was carried out in interrelated stages, namely; data presentation, data reduction, verification, and conclusion drawing. All results of data collection, both those 
obtained from in-depth interviews, observations and documentation were described and tabulated to be categorized according to the object of study, sub-objects, and indicators. For data that was lacking or irrelevant, the reduction was done by collecting files in specific folders which could be retrieved at any time if needed. The data that were doubtful or needed to be added or clarified were then verified and checked with the data obtained from different data collection methods. Next, all the data that had been collected were temporarily concluded. If the data were declared final, the final conclusion of the study was drawn.

\section{FINDINGS}

The findings of the study can be divided into two parts, namely; the forms of cultural diversity in the community of MIN Tegalasri, and the pattern of integration of environmental-based education.

\section{Research finding 1: The Forms of cultural diversity in the Community of MIN Tegalasri}

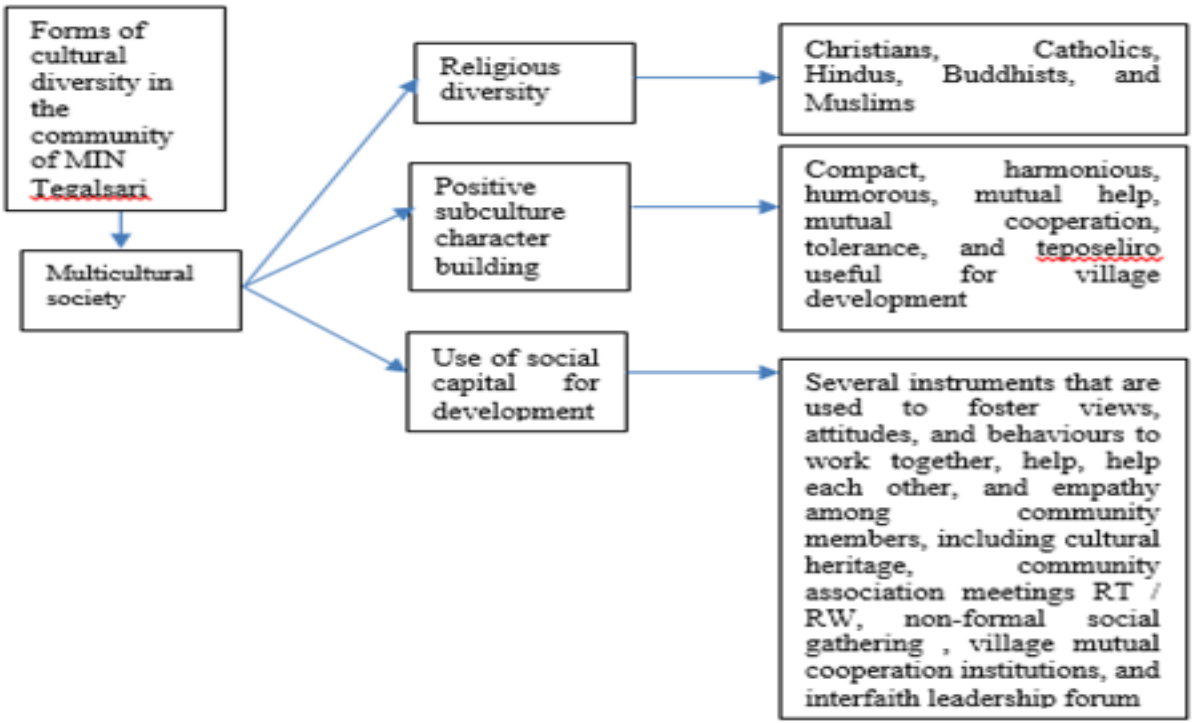

Figure 3

The Form of Cultural Diversity in the Community of MIN Tegalasri

The Tegalasri community is a collection of several families that are very diverse in terms of population, religion, and culture. The population of Tegalasri is 9,134 , which consists of 4,607 (50.44\%) male population and 4,527 (49.56\%) female population with $2,528(27.68 \%)$ family heads (KK). Most of them are Muslims (70, 35\%), others spread to Catholicism (9.49\%), Protestants (10.35\%), Hinduism (5.34\%), and Buddhism $(4.47 \%)$. Chart 1 shows the multicultural society in MIN Tegalasri. 


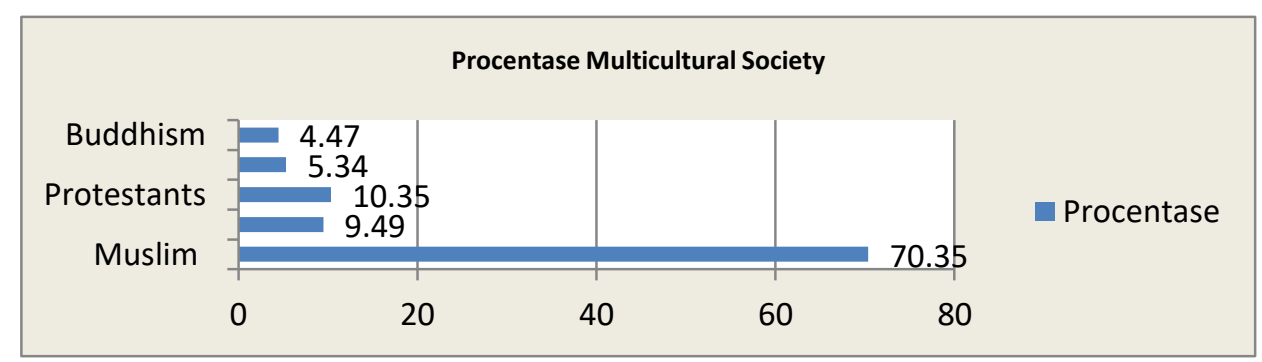

Figure 4

The Multicultural Society in MIN Tegalasri

Research finding 2: The pattern of integration of environmental-based school development in MIN Tegalasri

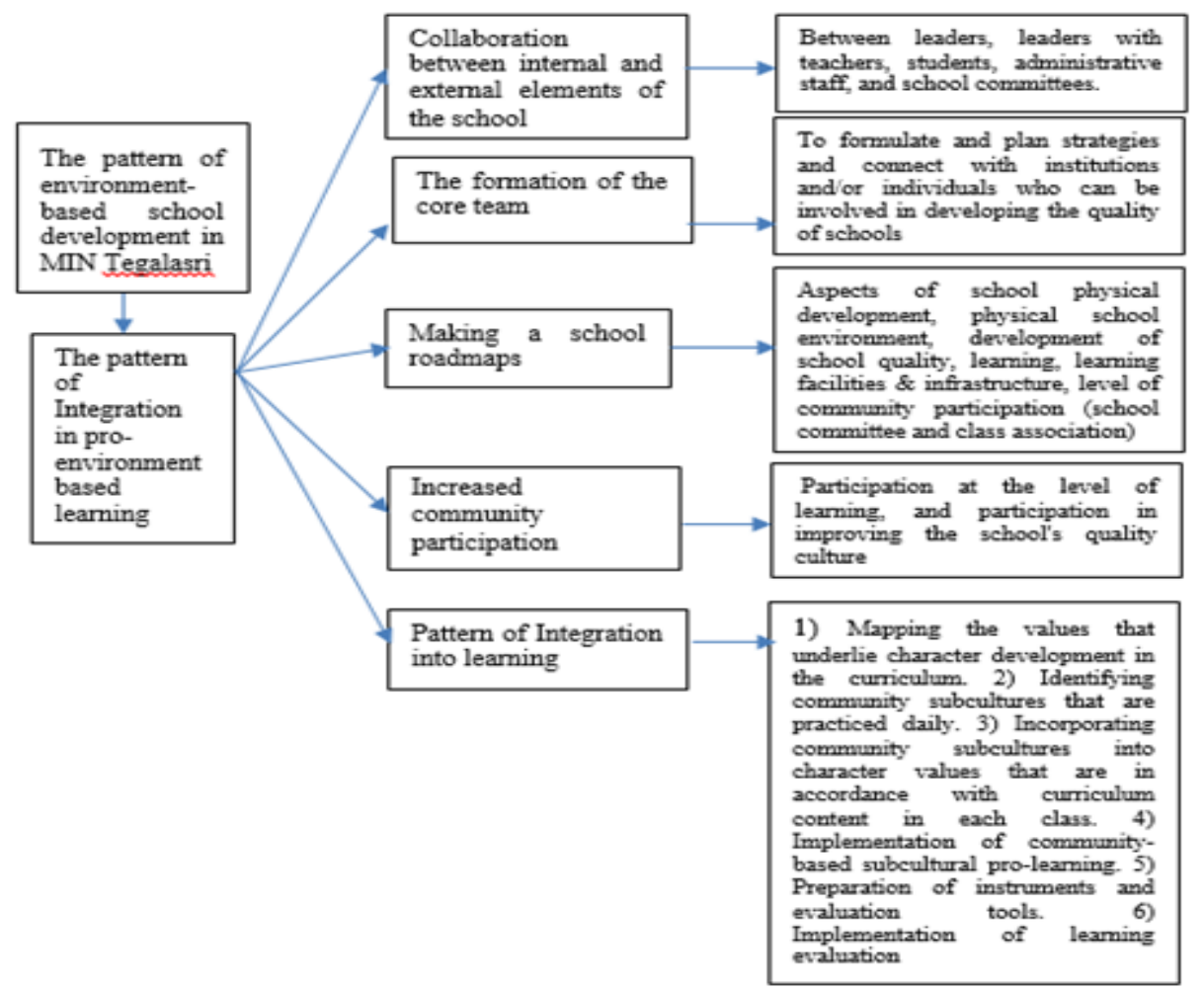

Figure 5

The Pattern of Integration of Environmental-Based School Development in MIN Tegalasri 
The first and second findings in figures 3 and 4 come from the results of in-depth interviews with research subjects. As for the in-depth interviews can be seen in Table 2 . As for chat 1 is the result of observations and documentation of data in MIN Tegalasri.

Table 2

Descriptive Subject Interview

\begin{tabular}{|c|c|}
\hline Subject says & $\begin{array}{l}\text { Code } \\
\text { subject }\end{array}$ \\
\hline $\begin{array}{l}\text { "The people here are various kinds of religion; there are Christians, Catholics, Hindus, Buddhists, } \\
\text { and Muslims. This condition has existed since I was a child, just look at this village there are also } \\
\text { various places of prayer for each religion " }\end{array}$ & CD1 \\
\hline $\begin{array}{l}\text { "In the context of society, the Tegalasri community develops mutual respect, tolerance, and } \\
\text { mutual assistance, does not see what religion is }\end{array}$ & CD2 \\
\hline $\begin{array}{l}\text { "the habits of the Tegalasri community help each other, mutual cooperation, help each other } \\
\text { benefit the school. We often ask for help from people/guardians who are members of the class } \\
\text { association to help with energy if the school needs it" }\end{array}$ & CD3 \\
\hline $\begin{array}{l}\text { "It is customary in this village, every time we build schools, places of worship, public places, and } \\
\text { other places we help each other and work together without regard to the origin of religion". }\end{array}$ & CD4 \\
\hline $\begin{array}{l}\text { "for neighbours who build houses, people here always take the time "Love", which is involved in } \\
\text { raising wood and precarious, both requested and unsolicited }\end{array}$ & CD5 \\
\hline $\begin{array}{l}\text { "Some school committee members and class associations transform the culture of society into } \\
\text { school culture, for example; a culture of cooperation, mutual cooperation, help, and harmony } \\
\text { between cultures/religions. According to respondents' acknowledgment that the cultural } \\
\text { conditions of the Tegalasri community make it possible to develop into a school culture" }\end{array}$ & CD6 \\
\hline $\begin{array}{l}\text { "But now everything has changed, this is because the school culture is developed based on the } \\
\text { culture of the local community so that they care and are involved in the development of quality" }\end{array}$ & CD7 \\
\hline $\begin{array}{l}\text { "Therefore, from the very beginning, the process of developing a school culture was optimized in } \\
\text { collaboration between internal elements of the school as subject" }\end{array}$ & CD8 \\
\hline $\begin{array}{l}\text { "The scope of cooperation developed, according to the principal includes, among others; school } \\
\text { culture, learning, school physical development, and learning evaluation, and end of semester } \\
\text { activities" }\end{array}$ & CD9 \\
\hline "The roadmap was prepared by the core team and was perfected in the school workshop forum" & CD10 \\
\hline $\begin{array}{l}\text { "This is where the role of the class association, among others, is to help students who experience } \\
\text { learning difficulties or are left behind with other friends. In the low class, especially assistance in } \\
\text { technical learning in the classroom, while in the high class the participation of guardians/parents } \\
\text { in the aspect of the end of semester activities or end of year activities" }\end{array}$ & CD11 \\
\hline $\begin{array}{l}\text { "While in the aspect of developing a school culture, community participation was developed } \\
\text { through school committees. School committees participate in the annual planning, } \\
\text { implementation, and evaluation of school programs, for example following a development } \\
\text { planning meeting" }\end{array}$ & CD12 \\
\hline $\begin{array}{l}\text { "Implementation of learning evaluation. According to one teacher, that environmentally } \\
\text { conscious learning based on community subcultures is generally carried out through three stages, } \\
\text { namely; planning, implementation, and evaluation" }\end{array}$ & CD13 \\
\hline
\end{tabular}

Overall the finding of the research study can be illustrated in figures 4 and 5 .

\section{DISCUSSION}

\section{The Forms of cultural diversity in the Community of MIN Tegalasri}

Tegalasri village is a community with diverse beliefs or religions, namely Christianity, Catholicism, Hinduism, Buddhism, and Islam. This condition has been going on since the ancestors. In each front of the house of a Hindu or Buddhist resident, there is always a single offering place, which is a rectangular size of $25 \mathrm{~cm}$ with a height of one meter, 
on which there is a place to place offerings. In front of the Village Hall there is a Christian church building, and to the north approximately $50 \mathrm{~m}$ there is a monastery building, while in the south of the Village Hall there is a Catholic church building. For residents who are Muslim, there are four mosques and one mosque. Religious diversity does not result in compartmentalized communities, but instead, they live in harmony, help each other, work together, and live in harmony.

The history of the existence of religious diversity of Indonesian society has existed since the Dutch colonial era. So far, there have never been clashes between the Tegalasri community due to religious differences. They live in harmony, respect each other, help each other, respect each other, and help. Both related to religious affairs/activities (according to the rules of each religious law) and in everyday life that tends to respect each other, tolerance, and help each other, do not look at religion. At the time of the construction of the mosque as a place of worship for Muslim religious students also came from Christian communities. Likewise, if there are cooperation activities to build school facilities, it has been going on for a long time. They volunteered to help according to their abilities and possessions. For example, there are those who help with energy, funds, and food. For preparing the school building, local people worked together to build it including a Hindu person donating his buffalo for the construction of an Islamic school building. Such an attitude, developed from generation to generation, became a habit and culture of diverse societies in religion. Even at the beginning of this school, seven students were non-Moslems. Likewise, Muslims in this village also help other religious residents when they need help. The growth of mutual assistance, caring, and cooperation is part of the long history of the Tegalasri community. The culture of unity in diversity that develops in society is a vital capital to drive progress in the field of education.

The forms of the subculture of the Tegalasri community are so harmonious, humorous where they have mutual help, cooperation, tolerance which are very useful for village development. Religious leaders, community leaders, and youth leaders did not experience difficulties in mobilizing village development activities, sports, public places, and places of worship. People help each other and greet at each other. It is customary in this village, every time we build schools, places of worship, public places, and other places, help each other and work together regardless of the origin of religion. In building a house, for example, the closest neighbors and relatives are also involved, especially when raising wood and roofs of the house, the community always takes the time to join "kesayan" event, in which people are involved in raising wood and roofs for their neighbor house even though they were not required to do so. The Tegalasri community is also famous for living harmoniously in cultural and religious diversity. According to the village head, so far, there has been no social friction caused by differences in views and religion. They can live harmoniously, help each other, and promote mutual respect in religious differences. Religious differences for the Tegalasri community are long-standing realities, and they have never experienced social clashes, the differences in religion understood by them are ancestral heritage. In their view, each religion teaches about values of mutual respect, respect for differences, and mutual assistance with others in need. 


\section{The pattern of Integration of Environmental Based Education}

The subculture of the Tegalasri community, which is good and developed from generation to generation, is internalized into school culture. Some school committee members and class associations transform the culture of society into school culture, for example culture of cooperation, helping each other, and living in harmony between cultures/religions. According to respondents, the cultural conditions of the Tegalasri community made it possible to develop into school culture. One form of community cultural transformation into school culture is the formation of a class association. The class association is a non-formal institution formed by schools to accelerate student independence in their learning. Class associations are formed from grade one to grade six. The member of class association was changed every year. This institution has different roles and responsibilities from the school committee because of the students' different ability in the learning for each class level.

According to the principal, long before the changing status of the school to be state school, this school was not maintained, public awareness was low, and teacher loyalty was also low. However, now everything has changed; this is because the school culture is developed based on the culture of the local community so that they care and are involved in developing school quality. Furthermore, according to the principal, the development of the school culture was taken in several steps. First, they formed the core team of the developer. The task of this team was to formulate and plan strategies and connect with institutions and people who can be involved in developing the quality of schools. The strategy that was built began with the creation of a master plan, basic concepts, and lobbying religious leaders, community leaders, youth leaders, and the business community (DUDI) in the local village and surrounding areas.

The second step was developing cooperation in internal and external institutions. According to the vice principal, all internal elements of the school are aware of the importance of cooperation between them, including cooperation in schools with the local community. Therefore, from the beginning, the process of developing a school culture was optimized by having collaboration between internal elements of the school such as collaboration between school leaders, leaders with teachers, students, administrative staff, and school committees. After internal cooperation is considered to be reliable, then the next step is to establish cooperation with external parties (individual or institutional). The scope of the cooperation developed, according to the principal includes school culture, learning, school physical development, and learning evaluation, as well as the end of semester activities. At the end of each semester, activities are usually held that integrate learning with environmental awareness so that students have the character of loving the environment and social sensitivity.

The third step was making a school quality development road map. The road map is a description of the development of school trips for a certain period in the future, which includes; aspects of school physical development, physical school environment, development of school quality, learning, learning facilities \& infrastructure, level of community participation (school committee and class association). The road map is always updated and adapted to the needs of the external environment because it is 
intended that school outcomes do not miss the dynamics of the community. Besides, road mapping also contains details of the stages of excellent cultural achievement in school development; short term, medium term, and long term. Including who does what and is responsible for what, so that every element in the school has roles and responsibilities following the collective agreement that has been prepared previously. According to the principal, the roadmap was prepared by the core team and was improved in the school workshop forum.

The fourth step was increasing community participation. Community participation is divided into two, namely; participation at the level of learning, and participation in improving the school's quality of culture. According to the principal, a class association has been formed, which serves to help students who have learning difficulties or are left behind with other friends. In grades 1,2 , and 3, intensive assistance was provided for the students for better learning in the classroom. In grade 4, 5, and 6, parental participation was provided to support end-of-year activities or year-end activities. Meanwhile, for developing a school culture, community participation was developed through school committees. School committees participate in the planning, implementation, and annual evaluation of school programs, for example, following development planning meetings. The community participates in the making of prayer rooms and bridges that connect between the old building and the new building.

The fifth step was integration of environment education into the school curriculum. The pattern of community subculture integration into the school curriculum is carried out through several stages of mapping the values that underlie character development in the curriculum, identifying community subcultures that are practiced daily, incorporating community subcultures into character values following curriculum content in each class, implementing pro-environment learning, preparing some instruments and evaluation tools, and implementing learning evaluation. According to one teacher, communitybased subculture-based learning is generally carried out through three stages, namely; planning, implementation, and evaluation. At the time of making learning and mapping planning as the researchers observed that teachers who supervised related subjects followed the activity. The activity was carried out in the form of a focus group discussion (FGD) forum and was well planned, all the grids discussed were written in full, making it easier for the guides to arrange the FGD agenda. To describe the findings clearly, they are summarized in Figure 2 and 3.

They have the same perspective and attitude in interpreting the reality of diversity that has been entrenched in a long time. In this view, the reality of religious diversity in Tegalasri existed since the Dutch colonial era. Awareness of religious diversity gives birth to subcultures in the community, for example, helping each other, mutual respect, and prioritizing the public interest. Such subculture is optimized to become social capital for the benefit of village development and institutions in the village. Social capital is the actual and potential overall resources related to the ownership of a fixed institutional relationship network based on mutual recognition (Bourdieu, 1986; Shahra, 2003). Every individual and community has social capital that will be useful to achieve common goals. Whether or not social capital is beneficial for the community depends on 
the ability of the leadership to mobilize for common interests. The forms of social capital in society are quite diverse, with different communities from one another, including; goodwill, a sense of friendliness, mutual sympathy, and close social relations and collaboration between individuals and families that form a social group (Hanifan, 1916). According to respondents, several instruments can be used to foster views, attitudes, and behaviors to work together, help each other, and give empathy among community members, including cultural heritage, community meetings, village cooperation institutions, and inter-religious leadership forum. Various instruments/channels that unite the community, in Tegalasri Village are followed by community members consisting of various religious backgrounds following the territorial concerned. According to Sunani (2017), school's multicultural education policy is applied based on the school founding fathers' philosophy, which emphasizes on merging nationalist and religious values. While in MIN Tegalasri it does not combine nationalist and religious values but rather the recognition of the diversity of various religions that have existed since the Dutch era embodied in social capital as a form of multicultural education with distinct characteristics different from other schools.

The ability of the community to mobilize and cultivate harmony between religious groups in Tegalasri Village can be analyzed through three basic things. First, the development of responsibility is based on obligations and expectations arising from mutual trust among community members. In the community members, there is a sense of mutual guarding and prioritizing social responsibility. Responsibility is an indicator of the nature of individuals and communities that are mature. Implementation of responsibility is part of a joint effort to realize shared hopes and goals. Second, there is transparency of information between the social structures of the community. Various structures and layers of community members obtain information transparently so as not to arouse suspicion. There are two channels of information that develop among the Tegalasri community, namely; formal channels such as neighborhood leader (Kasun), community association (RW), and neighborhood association (RT), and non-formal channels, for example through village communities, hobby groups, groups gatherings based on interests. Third, the norms and ethics of the society are adhered together. The norms and ethics of developing society are based on the universal values of each religion, social values, and the traditional values of society in a meeting

The potentials they have become social capital that can be beneficial for the development of quality in schools. This is a resource in the community that has not been utilized. The principal sees it as a profitable potential so that he develops a pattern of relations between the school and the community, for example through the gathering of class associations, routine and incidental meetings with school committees, and school bazaars with environmental themes involving all the potential of the surrounding community. Effective teaching of multicultural classes is unquestionably one of the biggest challenges that teachers face today (Chouari, 2016), so teacher should to understand the community especially student's religion and the culture of student in the school. 
Various research results show that in improving school quality, public trust, and excellent school culture requires collaboration with school stakeholders (Agustina \& Yuliani, 2006; Hidayat, 2013; Suti, 2011). The principal and school leadership board must realize that between the school and the community has a relatively good historical relationship. The dynamics, change, and improvement of school quality cannot be separated from the dynamics of the external world; society, culture, economy, politics and religion. Community participation, the collaboration between institutions, and a focus on the interests of customers (students and families) can increase school trust and quality. Based on the study, according to the principal's acknowledgment, the diversity of religious culture in Tegalasri village was used by the school as social capital to realize the goal of being a quality school that cares for the environment (Adiwiyata school).

The core team of school developers consists of seven people who come from various elements of the school, namely; board of school leaders, teachers, school committees, class associations, and community leaders. The main task of the core team is to make changes and development of school culture, and this model is in line with the results of research by Suyanto (2008). This teamwork is based on a decree made by the principal about the team's duties, authority, functions, and roles. The direction of change and development of school culture compiled by the core team is based on the vision, mission, and goals of the school. At the time the research was conducted MIN Tegalasri was developing adiwiyata schools, whose implementation was integrated with curriculum and community participation. Therefore, the core team has an important role and role in how the school community has a culture that leads to changes in mindset, attitude patterns, and patterns of caring for the environment.

Such cultural changes are carried out based on planning and study in a participatory manner to produce a road map for developing quality school culture. The road map is a blueprint or integrative guide for the development of an institution within a certain period (Yanuarsasi, 2014). The core team created a school quality development workshop attended by all leadership boards, teacher boards, school committees, class associations, and other stakeholders. The target of the workshop is to produce a formulation of a road map for the development of environment-based education by involving school stakeholders, both local communities with diverse cultures and groups or individuals outside the local community. The formulation of the road map is a mandate that must be realized by the core team. Therefore, the next step to take is to make a plan of action (PoA). The PoA contains activities, objectives, targets, indicators, time/date, costs, and the person in charge of activities. According to Balaji \& Millstein (2017), multi-cultural education is the main theme in education circles, so all education inevitably should pay attention to these phenomena in classroom learning. Many schools in multicultural areas turn a blind eye to the fact that the communities they serve are radical (Mallick \& Verma,1984), while people want children who want schools with cultural and religious backgrounds to also get the right to study at school. Therefore, this research adds to the experience of the school so that it is open to accepting students from a variety of cultures and religions, and schools can serve those differences. No secret, in America it turns out there is a multicultural flow and adopted in the world of 
education. The results of this study support the educational community in America (Bal, 2016) which is also ready to accept students with cultural and religious backgrounds.

Collaboration carried out by the school involves as many institutions and individuals as possible according to their capacity and authority. Collaboration is developed based on competency and scope of work by ignoring its socio-religious background. Elements of village institutions and individuals are involved following the needs of the school, both those with Islamic and non-Islamic backgrounds. The development of a culture of mutual assistance and cooperation in Tegalasri Village made it easier for schools to develop this culture of collaboration. Even at the beginning of the establishment of this school, there were seven students from non-Islamic schools who attended school in MIN Tegalasri. The scope of cooperation includes academic aspects, facilities and infrastructure, and the development of student interests. Based on the data the researchers obtained, several institutions that collaborated with MIN Tegalasri were village offices, parents (forming class associations, school committees), the village industry, interfaith forums, and several leaders of youth, religion, and society. According to "Education in a multi-ethnic country has a function not only to transfer the achievement of common human culture, but also, it must continue to be respected and respected cultural traditions of the dominant ethnic groups and ethnic minorities." this research supports this statement, where multiculturalism in education is needed in the current era (Zing, 2012).

Follow-up collaboration with several parties (institutions and individuals) is increasing community participation in school programs and activities. The three main elements of the school program are school managerial improvement, quality of learning, and involvement of school stakeholders. The three programs are then broken down into several activities, both in class and outside the classroom, routine-incidental, dailysemester, group, and individual. School managerial improvement is implemented in the form of; involving school stakeholders in activities, transparency in financial management, the involvement of school committees in the formulation of visions, missions, objectives, programs, and activities in annual and semester meetings, and formulation of activities in the form of action (PoA). Improving the quality of learning is implemented into fun learning, the school environment, and the community as a medium and source of learning, the involvement of all stakeholders in activities that support environment-based learning, synergizing the curriculum with environment-based learning, and at the end of the "environmental bazaar" event.

The environmental bazaar is an activity designed to enhance school collaboration, students, with the class association (community of parents) and the local community, exhibiting class work based on the natural environment around the village. This activity is also intended to increase the awareness of students and the local community that the social environment and the natural environment of the community can be used as a medium and as a learning resource also serves to maintain the balance of the ecosystem of the village environment as previous research shows that learning by utilizing the environment as a learning medium can increase motivation, creativity, and student competence (Halimah, 2008). The results of other studies indicate that there is a 
determination of learning by utilizing the environment as a learning medium with learning styles, and understanding students' concepts (Bintarini, Marhaeni, \& Lasmawan, 2012). All stakeholders are involved in class group activities starting from the stage; planning, coordination, implementation, and participatory evaluation. The scope of their involvement is in the form of thoughts, energy, and operational costs of the bazaar. A bazaar on the school grounds, which is attended by all student guardians, teachers, officials, and the public in general. How over study in multicultural based education should have potential implication for sociocultural awareness, thus, avoidance of such face-threat circumstances for better social interactions (Ambele \& Boonsuk, 2018).

The pattern of integration of environment-based education in schools is understood as an approach that includes; material, methodology, learning resources, and evaluate (Hakim, 2012). Also, learning methodologies that integrate environmental insights into the school curriculum can use the spider web method (Tarmiji, 2014). Furthermore, the results of this study indicate that the criteria for a green school curriculum include; cross-subject learning methods, material development, and personal ecology, ecological and cultural learning methods, biological curricular activities (Tarmiji, 2014). MIN Tegalasri commits and systematically develops programs to internalize religious, cultural, and social values in environmental-based education. Some activities carried out to integrate environmental education into the curriculum are mapping the subject and sub-topics of each subject, expanding the discussion of ecology across subjects, cultural and environmental based learning methods, school environment and the community as learning resources, curricular-based activities culture and environment. This will encourage students to study hard (Nauzeer \& Jaunky, 2019) and motivation for learning hardly.

\section{CONCLUSION}

Based on the findings of the study, some conclusions can be drawn. First, the Tegalasri community has a cultural diversity in terms of religion, socio-economic, and has good relationships between individuals and groups in society by developing an altruistic attitude, mutual assistance, cooperation in community development, and mutual respect for cultural diversity. Secondly, the integration of multicultural communities into the development of environment-based education in MIN Tegalasri is developed with five patterns of forming a core team, formulating the school stage roadmap, establishing internal and external cooperation carrying out activities together with the community and integrating the multicultural values into the school curriculum. The five activities are carried out in stages following a schedule prepared in the form of an environmentbased education plan of action (PoA). Preparation of a plan of action (PoA) is carried out with a participatory method between the core team of school developers by involving school stakeholders. The involvement of school stakeholders is quite comprehensive, starting from; problem assessment, action planning, coordination in program involvement, program implementation, and program evaluation. Finally, it can be concluded that the more intensive integration of community culture into the 
development of environment-based education and the more participation of the community, the more qualified the school will be.

The environment is an essential means that can be utilized by schools, besides as a learning media, it can also function to develop the personality image of students who have good character. Developing a positive attitude and caring for students about the surrounding environment is a necessity so that the environment becomes sustainable and maximally beneficial for the benefit of the wider community now and in the future. Instill care and love for the environment, as the results of this study, can be developed by integrating into education and the learning process by creating a culture in good schools. Creating a culture of caring about the environment in schools, with the hope that it can be implemented by all students in the family and community environment should be done as early as possible so that it grows into a pattern of knowledge, patterns of attitudes and daily behavior patterns.

The results of this study can be implemented by other schools using a participatory approach. The use of a participatory approach is based on the assumption that each community has the potential to be able to solve its group's problems. They have a flexible existence following the dynamics of the cultural development of their society. Efforts to develop a quality school culture and care for the environment can be made through stages; joint assessment of internal and external problems of the school, formulating objectives, forming a core team for developing school culture, formulating a plan of action (PoA) for developing school culture (producing programs and activities), coordinating implementation, implementing programs and activities for developing school culture, and joint monitoring and evaluation. It is important to understand also that the school culture implemented by a school whose results are capable cannot necessarily be implemented by other schools effectively because of the many influencing factors, including leadership and managerial abilities of the principal, skills, and motivation of the people involved, school culture, community culture, and so on. Therefore, for the next researcher it is necessary to examine the leadership and managerial abilities of the principal, skills, and motivation of the people involved, school culture, community culture, because of the diversity of people in different cultures and religions in Indonesia. so that other models in the development of multicultural-based schools can be raised.

\section{REFERENCES}

Agustina, \& Indrawati, Y. (2006). Faktor-faktor yang mempengaruhi kinerja guru matematika dalam pelaksanaan kurikulum berbasis kompetensi (KBK) pada sekolah menengah atas Kota Palembang. Jurnal Bisnis dan Manajemen, 4(7), 24-31.

Akkoyunlu, \& Yilmaz, S. (2008). A study of student's perceptions in a blended learning environment based on different learning styles. Educational Technology \& Society, 11(1), 183-193.

Ambele, E. A., \& Boonsuk, Y. (2018). Silence of Thai students as a face-saving politeness strategy in a multicultural university context. Arab World English Journal, 9(4), 221-231. DOI: https://dx.doi.org/10.24093/awej/vol9no4.16. 
Armia, C. (2002). Pengaruh budaya terhadap efektivitas organisasi: Dimensi budaya Hofstede. Jurnal Akuntansi dan Auditing Indonesia, 6(1), Juni, 103-117.

Ayala, G., \& Yano, Y. (1998). A collaborative learning environment based on intelligent agents. Expert Systems with Applications, 14(1-2), 129-137.

Bianco, L. J., \& Slaughter, Y. (2016). Recognizing diversity: The incipient role of intercultural education in Thailand. Book series of learning from difference: comparative accounts of multicultural education (pp.1-14). Switzerland: Springer.

Bal, A., \& Bianco, L. J. (2016). Introduction: Difference: Its expansion and consequences. Book series of learning from difference: comparative accounts of multicultural education (pp.15-34). Switzerland: Springer.

Bal, A. (2016). From deficit to expansive learning: Policies, outcomes, and possibilities for multicultural education and systemic transformation in the United States. Book series of learning from difference: comparative accounts of multicultural education (pp.171190). Switzerland: Springer.

Bianco.L.J. (2016). Multicultural education in the Australian context: An historical overview. Book series of learning from difference: comparative accounts of multicultural education (pp.191-219). Switzerland: Springer.

Bianco, L.J. (2016). Learning from difference. Book series of learning from difference: comparative accounts of multicultural education (pp.221-227). Switzerland: Springer.

Bagley, C., \& Verma, K. G. (1984). Self-concept and long-term effects of teaching about race relations in British schools. Book series of self-concept, achievement and multicultural education (pp.3-15). London and Basingstoke: Macmillan Press.

Balaji, M., \& Millstein, H. (2017). Beyond curry and caliphs: How advocacy in education has shaped Hindu Muslim relations in the United States. The Muslim World, 107, 287-298. DOI: 10.1111/muwo.12191.

Bintarini, N. K., Marhaeni, A. A. I. N., \& Lasmawan, I. W. (2012). Determinasi pemanfaatan lingkungan sekitar sekolah sebagai sumber belajar terhadap gaya belajar dan pemahaman konsep IPS pada siswa kelas IV SDN gugus yudistira Kecamatan Negara. Jurnal Pendidikan Dasar, 3(1). 1-11.

Bourdieu, Pierre. (1986). The forms of capital. In J. Richardson (Ed.), Handbook of theory and research for the sociology of education. Westport, CT: Greenwood.

Budimansyah, D. (2008). Peningkatan mutu pendidikan melalui penguatan partisipasi masyarakat. Educationist, 2(1), 56-63.

Burns, B. R. (1984). The relative influences of ethnicity, social class and religion of stimulus person on social distance. Book series of self-concept, achievement and multicultural education (pp.17-37). London and Basingstoke: Macmillan Press.

Chamlian, C. H., \& Kowalewski, P. D. (2016). Multiculturalism in the Brazilian education: Challenges and perspectives. Book series of learning from difference: comparative accounts of multicultural education (pp. 99-124). Switzerland: Springer. 
Chou, S. W., \& Liu, C. H. (2005). Learning effectiveness in a web-based virtual learning environment: A learner control perspective. Journal of Computer Assisted Learning, 21(1), 65-76.

Chouari, A. 2016. Cultural Diversity and the challenges of teaching multicultural classes in the twenty-first century. Arab World English Journal (AWEJ), 7(3), 3-17.

Keil, C., Haney, J., \& Zoffel, J. (2009). Improvements in student achievement and science process skills using environmental health science problem-based learning curricula. Electronic Journal of Science Education, 13(1), 1-18.

Desfandi, M. (2015). Mewujudkan masyarakat berkarakter peduli lingkungan melalui program adiwiyata. Sosio-Didaktika: Social Science Education Journal, 2(1), 31-37.

Efianingrum, A. (2007). Kultur sekolah yang kondusif bagi pengembangan moral siswa. Artikel Majalah Dinamika Pendidikan No. 01/Th. IV Mei.

Ernst, J., \& Monroe, M. (2004). The effects of environment-based education on students' critical thinking skills and disposition toward critical thinking. Environmental Education Research, 10(4), 507-522.

Epstein, E. I. (2010). "Who are your Friends?" complexities in multicultural education. Urban Rev, 42, 39.57. DOI: 10.1007/s11256-008-0118-6.

Gay, L. R., Mills, G. E., \& Peter, A. (2012). Educational research: Competencies for analysis and applications. New Jersey: Pearson Education.

Gordon, D. E. (2010). Green schools as high performance learning facilities. Washington, DC: National Clearinghouse for Educational Facilities.

Hakim, L. (2012). Model integrasi pendidikan anti korupsi dalam kurikulum pendidikan Islam. Jurnal Pendidikan Agama Islam Ta'lim Volume, 10, 141-156

Halimah, L. (2008). Pemberdayaan lingkungan sebagai sumber belajar dalam upaya meningkatkan kompetensi berbahasa Indonesia siswa kelas 4 SD laboratorium UPI Kampus Cibiru. Jurnal Pendidikan Dasar. Nomor, 10.

Hanifan, L. J. (1916). The rural school community center. Annals of the American Academy of Political and Social Science, 67, 130-138

Horst, C. (2016). Educational responses to ethnic complexity in education: Experiences from Denmark. Book series of learning from difference: comparative accounts of multicultural education (pp.69-98). Switzerland: Springer.

Hidayat, S. (2013). Pengaruh kerjasama orang tua dan guru terhadap disiplin peserta didik di sekolah menengah pertama (SMP) Negeri Kecamatan Jagakarsa-Jakarta Selatan. Jurnal ilmiah WIDYA, 1(2). 92-99.

Kholis, N., Zamroni, Z., \& Sumarno, S. (2014). Mutu sekolah dan budaya partisipasi stakeholders. Jurnal Pembangunan Pendidikan: Fondasi dan Aplikasi, 2(2).

Leite, L., Dourado, L., Morgado, S., \& Antunes, M. (2019). Teacher education and popular culture: proverbs about the climate and weather. Journal of Turkish Science Education. 16(1), 1-17. 
Mallick, K., \& Verma, K. G. (1984). Teaching in the multiethnic, multicultural school. Book series of self-concept, achievement and multicultural education (pp.146-149). London and Basingstoke: Macmillan Press.

Neo, M., \& Neo, K. T. (2001). Innovative teaching: Using multimedia in a problembased learning environment. Educational Technology \& Society, 4(4), 19-31.

Nauzeer, S. \& Jaunky, V.C. (2019). Motivation and academic performance: A SEM approach. International Journal of Environmental and Science Education, 14(1), 41-60

Nugroho, A. M., \& Nikmah, K. (2018). Islamic education concepts insightful of harmony on multicultural community. Millah, 17(2), 337-378.

Özsoy, S., \& Bilgi, S. (2016). Multicultural education perspective in Turkey: Possibilities and dilemmas. Book series of learning from difference: comparative accounts of multicultural education (pp.99-144). Switzerland: Springer.

Rahman, B. (2014). Kemitraan orang tua dengan sekolah dan pengaruhnya terhadap hasil belajar siswa. Jurnal Pendidikan Progresif, 4(2), 129-138.

Rahman, K. A. (2012). Peningkatan mutu madrasah melalui penguatan partisipasi masyarakat. Jurnal Pendidikan Islam, 1(2), 227-246.

Reva J. R., Peck, C., Thompson, A. L., Chareka, O., \& Sears, A. (2016). Multicultural education, diversity, and citizenship in Canada. Book series of learning from difference: comparative accounts of multicultural education (pp.35-68). Switzerland: Springer.

Roza, P. (2007). Pendidikan dan mutu manusia. Jurnal Sosioteknologi, 6(12), 303-308.

Ruyadi, Y. (November, 2010). Model pendidikan karakter berbasis kearifan budaya lokal (penelitian terhadap masyarakat adat kampung benda kerep Cirebon provinsi jawa barat untuk pengembangan pendidikan karakter di sekolah). In Proceedings of the 4th International Conference on Teacher Education; Join Conference UPI \& UPSI Bandung, Indonesia.

Sisdiknas, U. U. (2003). Undang-undang republik Indonesia Nomor 20 Tahun 2003 Tentang Sistem Pendidikan Nasional, pasal 1 ayat 2. online), www. inherent. dikti. net/files/sisdiknas. pdf, diakses pada tanggal, 15 Juli 2017.

Soudien, C., \& McKinney, C. (2016). The character of the multicultural education discussion in South Africa. Book series of learning from difference: comparative accounts of multicultural education (pp.125-145). Switzerland: Springer.

Sudarsana, I. K. (2016). Peningkatan mutu pendidikan luar sekolah dalam upaya pembangunan sumber daya manusia. Jurnal Penjaminan Mutu, 1(1), 1-14.

Sunani, (2017). Implementasi pendidikan multikultural dalam budaya sekolah di SMA terpadu Krida Nusantara Bandung. Jurnal Pendidikan Ilmu Sosial. 26(1), 53-63.

Suti, M. (2011). Strategi peningkatan mutu di era otonomi pendidikan. Jurnal Medtek, 3, 1-6 
Suyanto, S. (2008). Pengembangan sekolah bertaraf internasional melalui organisasi belajar: konsep dan implementasi. Jurnal Cakrawala Pendidikan, 3(3), 241-249.

Syahra, R. (2003). Modal sosial: Konsep dan aplikasi. Jurnal Masyarakat dan Budaya, 5(1), 1-22.

Tarmiji, A. (2014). Menuju green school: Penerapan kurikulum pembelajaran berwawasan lingkungan di institusi Pendidikan. In Makalah Seminar Program Doktorat PS Sosiologi Pedesaan. Sekolah Pascasarjana, Institut Pertanian Bogor. [tehubung berkala. http://www. skpm. ipb. ac. id (Vol. 1). 1-16.

Wangid, M. N. (2009). Pengembangan model ketahanan sekolah berbasis budaya sekolah. PPB FIP UNY. Yogyakarta.

Wang, Y., Ye, H., \& Schapper, A. (2016). Multiculturalism and multilingual education for minority ethnic groups in China: Examples of Southwest China and Xinjiang Uygur regions and the goal of educational equality. Book series of learning from difference: comparative accounts of multicultural education (pp.51-68). Switzerland: Springer.

Yanuarsasi, P. (2014). Revitalisasi polri menuju pelayanan prima (studi pada polres Tulungagung). Jurnal Administrasi Publik, 2(1), 182-188.

Zing, T. (2012). Cultural diversity and integrated multicultural education. Front. Educ. China, 7(2), 163-168. 